\title{
Comparative Analysis of Commercial Banks Liquidity Position: The Case of Tanzania
}

\author{
Xuezhi Qin ${ }^{1} \&$ Dickson Pastory ${ }^{1}$ \\ ${ }^{1}$ School of Business Management, Dalian University of Technology, Dalian, China \\ Correspondence: Dickson Pastory, School of Business Management, Dalian University of Technology, Dalian \\ 116024, China. Tel: 86-188-4268-6991.E-mail: passtory1@yahoo.co.uk
}

Received: February 11, 2012 Accepted: March 5, 2012 Online Published: May 16, 2012

doi:10.5539/ijbm.v7n10p134 URL: http://dx.doi.org/ijbm.v7n10p134

\begin{abstract}
This paper gives an overview picture of commercial banks liquidity position in Tanzania for the period of ten years (2000 to 2009). The study employed the liquidity measures of commercial banks, and on that basis the performance in terms of liquidity position was established. The paper used the casual research design as the methodology of the study since the casual design is best suited to determine cause and effects of the phenomenon. This paper utilizes secondary data from National Bank of Commerce (NBC), CRDB and National Microfinance Bank (NMB). The criteria used is total deposit to core funding, liquid asset to demand liabilities and Gross loans to total deposit Tanzania for the period of ten years, and finally the hypothesis was tested to know whether there is a significant difference in terms of liquidity position by using ANOVA test. The findings revealed that the commercial banks under study have strongest liquidity level although it varied over years and National Microfinance Bank maintained strongest liquid level compared to the other two banks.
\end{abstract}

Keywords: liquidity measures; financial statements analysis, commercial banks, ANOVA test, financial statement analysis, Tanzania

\section{Introduction}

Liquidity level refers to the ability to have enough funds to meet the long-term and shortem obligations. Liquidity problems of commercial banks started long time years ago before financial reforms, many commercial banks were witnessed undergoing insolvency due to higher level of non-performing loans (chijoriga, 1997). With those liquidity problems the government of Tanzania decided to make institutional and economic innovation towards the impediment of the financial systems. Among the measures adopted is the liberalization of the market forces so as to create the fair play ground to the economic system. The adopted liberization of economic system increased the efficiency, liquidity and enhance competition in the financial system (Aikaeli, 2008). The market liberalization increased the banking industry and shift the markets from the government owned banks to private owned banks. Recently there are about 43 banking institutions which do compete for the supply of the financial services (BOT, 2011).

Commercial banks are the most significant instrument in the economy and in most cases are viewed as the public goods, therefore the liquidity position need to be stable. In the context of Tanzania environment they carry more than $96 \%$ of the total assets of the banking assets (Timothy, 2010). The growth of any economy depends on the liquidity position of commercial banks as they provide in terms of loans to MFIs, the government and the people at large. The recent economic crisis in Europe and America give the world cautions to periodically review the financial structure in terms of assets, liquidity, capital adequacy etc. Moreover the functioning of the capital markets and money market depends much on the liquidity position of the commercial banks. To ensure the activities of commercial banks does not hampered there is a need to confirm on the liquidity position of commercial banks (BOT, 2009). The study adopted traditionally ratio analysis to measure the liquidity position of commercial banks.

Liquidity position of commercial banks is normally monitored and measured by liquidity ratio (Rychtarik, 2009). The significant items that was diagnosed includes the liquidity position measures such as total deposit to core funding position, liquid assets to demand liabilities and gross loans to demand liabilities. The study was to examine a set of commercial banks providing services to the same economy and operating in the same environment. Moreover the study was interested in establishing differences, if any, in relative degrees of liquidity 
position of these commercial banks. The ratio of total deposit to total Funding, liquid assets to demand liabilities and gross loans to total deposit were used as the measurement criteria.

To crown up it all, new challenges and opportunities come with liquidity that the bank has which finally can affect the efficiency of the banks.

The paper contributes the literature in Tanzania banking system in the following manner:

The liquidity measure will give any indication whether the commercial banks are operating at higher level of liquidity or not and the development of capital market is still in infancy stage this will give confidence to the policy markers, bank management and stakeholders to overcome challenges arising in commercial banks

\section{Literature Review}

\subsection{Theoretical Review}

\subsubsection{Ratio Analysis}

Ratio analysis involves comparisons because company ratios are compared with those of other firms in the same industry, that's the industry average figures. Also, managers usually go a step further and compare their ratios with those of smaller set of leading companies in their industry.

This technique is called benchmarking. With benchmark ratio are calculated for each company and they are listed in descending order. (Foster, 1986)

\subsubsection{Usefulness of Ratio Analysis}

According to Baisi (2005) and Foster (1986) ratio analysis has the following importance.

1) It provides the framework for the decision making

2) It is used by analyst to judge the performance of the company

3) It is used in credit analysis to make judgment with regard to provide loans or not, it is frequently used by the banks.

\subsubsection{Limitations of Ratio Analysis}

1) Different accounting and operating practices of the commercial banks can distort comparisons. For example, inventory valuation and depreciation methods can affect financial statements thus, distort comparisons among commercial banks.

2) It is difficult to generalize about whether or not a particular ratio is good. For example, a high current ratio may indicate a strong liquidity position, which is good or excessive cash that is bad because excess cash in the bank is a non-earning asset.

3) Inflation may have badly distorted the company's balance sheet, that is, recorded values are often substantially different from true values. Therefore, depreciation charges, inventory costs and profits may also affected.

4) When univariate analysis technique is used, some ratios may look good while others may look bad making difficult to judge whether the company is performing good or bad.

5) The decision on cutoff point is somehow difficult to make in order to make decision.

6) Commercial banks also employ window dressing techniques to make their financial statements look better than they really are so as to attract interested parties such as investors and Financial Institutions.

7) Those ratios targeted to compare performance against the industrial standard may not be effective because the industrial standard may not exit.

\subsubsection{Financial Performance}

Performance evaluation entails the analysis of the level of financial and economic performance using both the qualitative and the quantitative data. In this case there are two possible ways of analysis that is basically quantitative in nature and qualitative in nature On the case of qualitative they can't be quantified but they basically influence the performance of the entities (Shapiro, 1991). Financial performance can easily be calculated by looking the components of the financial statements which are the income statements, balance sheet and the statement of equity changes (ACCA, 2007).These components help to depict the true picture of the business by relating the items of the components of the financial statements. A comparison of ratios of the same firm over time is important in evaluating changes and trends in the firm's financial condition including profitability. This comparison may be judged with those of similar firms in the same line of business and when 
appropriate with an industrial averages (Horne, 2000).

\subsubsection{Financial Statement Analysis}

This seeks on establishing the relationships with the set of financial statements at a point in time with trends in these relationships over time (Baisi 2005). Financial statements analysis involves the analysis and interpretations of financial statements in order to identify the strength and weakness of the company. The financial statements analysis is the process of establishing the relationship between various items of balance sheet and income statements. Financial statement analysis is a part of a larger information processing system on which informed decisions can be based upon (Varn Horne, 2000). The evaluation of financial statements takes the historical information for the number of years. The evaluation can be of trend analysis or cross sectional analysis. Normally the historical financial statements provide the reliable source of information for predicting the future performance of the business. In making financial statements analysis various parties need to be satisfied existing and potential stakeholders, employees, suppliers, competitors, governments, and the public at large. The needs of the above group are different and each group has its own set of need e.g. management need financial statement for profit maximization but the shareholders need financial statements for wealth maximizations and overall prospect of the company (Bais, 2005).

\subsubsection{Liquidity Position Analysis}

This refers to the ability of commercial banks to pay its obligations as it falls due and the level of funding. It includes core deposits to total deposits; this ratio is calculated by summing of all core deposits divided by total deposit, it measures the volatility of deposits. Liquid assets to demand liabilities this is calculated by taking the sum of all assets maturing within one year divided by all liabilities with the same maturity period. This intends to capture the liquidity mismatch of assets and liabilities and provides an indication of the extent to which banks could meet short term withdrawal of funds without facing liquidity problems. Gross loans to total deposits this is calculated by taking gross loans divided by total deposits, measure the extent to which deposits have financed loan portfolio which are considered illiquid assets (BOT, 2007).

In commercial banks liquidity refers to the reserve of cash, securities, a bank ability to convert an asset into cash, and unused bank lines of credit, the faster the conversion the more the liquid is the asset. Liquidity must be sufficient to meet all maturing unsecured debt obligations due within a one year time horizon without incremental access to the unsecured market, probably the most critical issue to examine for the bank ability to meet obligation. If the earning is poor and liquidity is high the bank lending may be conservative with high proportions of proceeds from deposits are invested in low yielding assets. If earnings are aggressive lending policy coupled with heavy borrowing. The key ratios are; loans as a percentage of deposits that is loan to total deposits, liquid asset to total deposit and loan loss or non-performing loans to total loan (Vinolas, 2003). Liquidity and funding, funding is what a bank relies upon to grow its business, it is provided by deposits, shortem debt and longer term debt, funding it means access to capital.

Liquidity is what a bank requires if funding is interrupted and the bank must still to maintain its obligation, the bank deposit rate indicate how the bank is financing the balance sheet, it is taken by subtracting the deposit of the previous year from the deposit of the previous year and divide by deposit of the current year .

\subsection{Empirical Review}

In this case there are substantial researches which have been made with regard to bank liquidity, among of them are: Vodava (2011) made analysis of liquidity of Czech commercial banks and its determinant, his results showed that there is a positive link between liquidity and capital adequacy. Shin (2007) indicated that in turbulent economic sphere liquidity position is very important as any changes will bring the changes in the network of the banks. Nikolaon et al (2009) in their paper funding liquidity risk definition and measurements pointed that funding for liquidity are stable and sometimes low in turmoil period, therefore liquidity management is necessary. Moreover in the Nordic investment policy (2009), it has been pointed out that bank liquidity is very important to meet both un expected and expected losses, it includes both cash and cash equivalent, placement with other banks and investment in securities, therefore liquidity is very crucial as it can absorb loses and increase profitability of the commercial banks. Basel committee (2009) indicated that the liquidity level of the commercial banks is the paramount importance for the sustainability of the banks and they further indicated that the entire inner role of the bank is to ensure the stability of the cash flow. Barua (2001) in his paper liquidity scenario in commercial banks of Bangladesh, the results showed that liquidity level has been dropped by $2 \%$ due to excess government borrowing and inconsistent growth of deposit. This has been supported by the liquidity ratio. In Tanzania literature few studies have been conducted with regard to commercial banks liquidity except that of Aikaeli (2006) wrote on determinant of excess liquidity in commercial banks in Tanzania of which his 
findings showed that high cost of funding, credit risks, volatility of deposit holders, cash preference are the main contributors of excess liquidity in commercial banks.

\section{Methodology of the Study}

The study used panel secondary data collected from the respective commercial banks, and it includes published financial reports and audited reports from the commercial institution for the period of 2000 to 2009 .Exploratory research design is suitable for exploratory studies whose main emphasis is to formulate a problem for more precise investigation or developing a working hypothesis from an operational point of view. The major emphasis is on the discovery of ideas and insight; as such the research design appropriate for such studies must be flexible enough to provide opportunity for considering different aspects of a problem under study (Kothari, 1998). In descriptive research design, the major emphasis is on determining the frequency with which something occurs or the extent to which two variables differs. Descriptive studies are also concerned with specific predictions, narrations of facts and characteristics concerning individuals, groups or situation. The comparative study employed a descriptive type of design due to the fact that there were empirical studies which exist on performance evaluation of different companies. As Kothari (1998) puts "it is necessary to have a clear picture of the phenomenon on which you wish to collect data prior to the collection of data" This means that a descriptive study pre-supposes much prior knowledge about the phenomenon being studied. The strategy of the study was a cross sectional meaning that it covered a certain period of time and the use of time series data. Performance was measured using financial measurement. Financial variables were computed ratios which pin pointed which commercial bank is better; the secondary data collected was processed by SPSS where all the required performance measures were calculated. Statistical analysis was employed in order to test the validity of the hypotheses.

\section{Findings and Results}

\subsection{Analysis of Liquidity}

The paper seeks to analyse the liquidity position of the commercial banks. To achieve this, The results was analysed using the comparative core deposits to total funding, liquid assets to demand liabilities and gross loans to total deposit as presented in Tables 1,2,3 and 4 which were the computed actual results.

Table 1. Bank of Tanzania liquidity measure

\begin{tabular}{lccc}
\hline Ratings & $\begin{array}{c}\text { Core deposit to total } \\
\text { funding }\end{array}$ & $\begin{array}{c}\text { Liquid asset to demand } \\
\text { liabilities }\end{array}$ & $\begin{array}{c}\text { Gross loans to total } \\
\text { deposit }\end{array}$ \\
\hline 1 & Above $80 \%$ & Above $40 \%$ & Below $70 \%$ \\
2 & $60 \%-80 \%$ & $30 \%-40 \%$ & $70 \%-75 \%$ \\
3 & $40 \%-60 \%$ & $20 \%-30 \%$ & $75 \%-80 \%$ \\
4 & $20 \%-40 \%$ & $15 \%-20 \%$ & $80 \%-85 \%$ \\
5 & Below 20\% & Below $15 \%$ & Above $85 \%$ \\
\hline
\end{tabular}

\subsubsection{Analysis of Core Deposit to Total Funding}

Table 2 shows that commercial bank's liquidity measured by Comparative core deposits to total funding was higher to NMB and raising slightly over time, while that of CRDB and NBC are not consistency. The trend of CRDB and NBC was fluctuating as it was low in 2008, picked up in 2009 in case of CRDB and NBC declined in 2008 and 2009. NMB has been able to maintain the highest core deposit to total funding ratio in the four years followed by NBC. In 2000 to 2005 all commercial banks were having an excellent liquidity level in terms of core deposit to total funding. Also, in 2006 up to year 2009 NMB showed strong liquidity levels and well developed funds management practices. The institution has reliable access to sufficient sources of funds on favorable terms to meet present and anticipated liquidity needs. CRDB and NMB showed satisfactory liquidity levels and funds practices in the period of the year 2006 to year 2009. The institutions have access to sufficient sources of funds on acceptable terms to meet liquidity needs; modest weakness may be evident in funds management. 
Table 2. Comparative core deposits to total funding

\begin{tabular}{llll}
\hline Year & CRDB & NMB & NBC \\
\hline 2000 & $63.90 \%$ & $70.52 \%$ & $55.46 \%$ \\
2001 & $67.98 \%$ & $89.54 \%$ & $74.96 \%$ \\
2002 & $71.52 \%$ & $89.19 \%$ & $81.86 \%$ \\
2003 & $74.96 \%$ & $92.19 \%$ & $79.77 \%$ \\
2004 & $80.96 \%$ & $90.34 \%$ & $79.15 \%$ \\
2005 & $69.24 \%$ & $95.70 \%$ & $80.48 \%$ \\
2006 & $70.77 \%$ & $94.87 \%$ & $77.64 \%$ \\
2007 & $77.41 \%$ & $95.41 \%$ & $79.99 \%$ \\
2008 & $66.40 \%$ & $96.71 \%$ & $74.91 \%$ \\
2009 & $67.07 \%$ & $97.89 \%$ & $73.59 \%$ \\
\hline
\end{tabular}

Source: Field data, 2010

\subsubsection{Analysis of Liquid Assets to Demand Liabilities}

Table 3 shows that commercial bank's liquidity measured by liquid assets to demand liabilities was raising slightly to NMB while that of CRDB and NBC was not consistency.NBC and CRDB liquid assets to demand liabilities was fluctuating as it was low in 2008; picked up in 2009.

Table 3. Comparative liquid assets to demand liabilities

\begin{tabular}{lccc}
\hline Year & CRDB & NMB & NBC \\
2000 & $49.12 \%$ & $44.40 \%$ & $71.44 \%$ \\
2001 & $67.32 \%$ & $43.35 \%$ & $66.02 \%$ \\
2002 & $58.53 \%$ & $56.50 \%$ & $74.73 \%$ \\
2003 & $67.62 \%$ & $65.99 \%$ & $70.33 \%$ \\
2004 & $44.72 \%$ & $67.70 \%$ & $59.30 \%$ \\
2005 & $64.08 \%$ & $76.51 \%$ & $56.44 \%$ \\
2006 & $50.23 \%$ & $94.87 \%$ & $54.71 \%$ \\
2007 & $50.49 \%$ & $95.41 \%$ & $50.59 \%$ \\
2008 & $40.03 \%$ & $96.71 \%$ & $38.92 \%$ \\
2009 & $47.72 \%$ & $97.89 \%$ & $43.18 \%$ \\
\hline
\end{tabular}

Source: field data, 2010

Of all these commercial banks, NMB has been able to maintain the highest liquid assets to demand liabilities in the four years followed by CRDB. Financial performance measured by liquid assets to demand liabilities was strong liquidity levels and well developed funds management practices, the institutions have reliable access to sufficient sources of funds on favorable terms to meet present and anticipated liquidity needs this was for the three commercial banks for the entire period with exception to NBC in the year 2008 which showed satisfactory liquidity levels and funds practices. The institution has access to sufficient sources of funds on acceptable terms to meet liquidity needs; modest weakness may be evident in funds management.

\subsubsection{Analysis of Gross Loans to Total Deposit}

Table 4 shows that commercial banks liquidity measured by Gross loan to total deposit was fluctuating from 2000 to 2002 for CRDB and NMB while that of NBC was rising with the exceptional to the year 2009, however the CRDB and NMB liquidity was also increasing from 2003 with the exceptional to the year 2009. Of all these commercial banks NBC has been able to maintain the highest gross loan to total deposit in the four years followed by CRDB. Financial performance measured by gross loans to total deposit was strong liquidity levels and well developed funds management practices, the institutions have reliable access to sufficient sources of 
funds on favorable terms to meet present and anticipated liquidity needs this was for the three commercial banks for the entire period in 2000 to 2009 with exception to NBC in the year 2008 which showed liquidity level and funds management practices need improvement. The institution lacked ready access to funds on reasonable terms or might evidence significant weakness in funds management practices.

Table 4. Comparative gross loans to total deposit

\begin{tabular}{lccc}
\hline Year & CRDB & NMB & NBC \\
\hline 2000 & $25.25 \%$ & $0.10 \%$ & $21.40 \%$ \\
2001 & $19.45 \%$ & $4.18 \%$ & $25.98 \%$ \\
2002 & $17.05 \%$ & $2.80 \%$ & $28.43 \%$ \\
2003 & $18.99 \%$ & $7.74 \%$ & $43.73 \%$ \\
2004 & $38.38 \%$ & $16.23 \%$ & $48.91 \%$ \\
2005 & $30.91 \%$ & $13.58 \%$ & $53.18 \%$ \\
2006 & $51.96 \%$ & $20.58 \%$ & $53.88 \%$ \\
2007 & $59.50 \%$ & $39.12 \%$ & $60.79 \%$ \\
2008 & $66.91 \%$ & $49.13 \%$ & $75.80 \%$ \\
2009 & $60.85 \%$ & $47.41 \%$ & $68.03 \%$ \\
\hline
\end{tabular}

Source: field data, 2010

\subsection{Overall Description of Liquidity Performance of the Banks}

With analysis of Tables 2, 3, and 4, the commercial banks financial performance depicts that in year 2006 CRDB, NMB and NBC was having good and sound financial position in terms of liquidity. All commercial banks were operating above the set standard by the bank of Tanzania. In year 2007 the facts are the same; the commercial banks maintained a strong liquidity level especially in terms of liquid assets to demand liabilities. In the year 2008 CRDB and NMB maintained strong liquidity level showing that the banks are having sound financial position and strong performance in every respect, but NBC in this year is having strong performance but close monitoring on trend of components was needed. In 2009 there was an improvement of NBC liquidity performance into sound financial position and also CRDB and NMB maintained a strong liquidity level.

\subsection{Hypothesis Testing}

"There is no significant difference in the liquidity position among commercial banks."

ANOVA test

H0: There was no significant difference in liquidity positions among commercial banks in Tanzania

H1: There was a significant difference in liquidity positions among commercial banks in Tanzania

Results of the test of significance at $95 \%$ Confidence interval (that is, 0.05 level of significance) for liquidity indicated the following results.

Table 5. Core deposits to total funding

\begin{tabular}{lccccc}
\hline & Sum of Squares & Df & Mean Square & F & Sig. \\
\hline Between Groups & 2233.870 & 2 & 1116.935 & 22.424 & 0.000 \\
Within Groups & 1344.892 & 27 & 49.811 & & \\
Total & 3578.762 & 29 & & & \\
\hline
\end{tabular}

Table 6. Mean and standard deviation table of core deposits to total funding

\begin{tabular}{lccc}
\hline Banks & Mean & $\mathrm{N}$ & Standard deviation \\
\hline CRDB & 71.0210 & 10 & 5.32836 \\
NMB & 91.2360 & 10 & 7.90727 \\
NBC & 75.7810 & 10 & 7.64958 \\
Total & 79.3460 & 30 & 11.10881 \\
\hline
\end{tabular}


Table 7. Liquid asset to demand liabilities

\begin{tabular}{lccccc}
\hline & Sum of Squares & Df & Mean Square & F & Sig. \\
\hline Between Groups & 2183.346 & 2 & 1091.673 & 4.609 & 0.019 \\
Within Groups & 6395.683 & 27 & 236.877 & & \\
Total & 8579.029 & 29 & & & \\
\hline
\end{tabular}

Table 8. Mean and standard deviation table of liquid assets to demand liabilities

\begin{tabular}{lccc}
\hline Banks & Mean & N & Standard deviation \\
\hline CRDB & 53.9860 & 10 & 9.75316 \\
NMB & 73.9330 & 10 & 21.63423 \\
NBC & 58.5660 & 10 & 12.14362 \\
Total & 62.1617 & 30 & 17.19967 \\
\hline
\end{tabular}

Table 9. Gross loans to total deposit

\begin{tabular}{lccccc}
\hline & Sum of Squares & Df & Mean Square & F & Sig. \\
\hline Between Groups & 4057.745 & 2 & 2028.872 & 5.784 & .008 \\
Within Groups & 9470.922 & 27 & 350.775 & & \\
Total & 13528.667 & 29 & & & \\
\hline
\end{tabular}

Table 10. Mean and standard deviation table of Gross loans to total deposit

\begin{tabular}{lccc}
\hline Banks & Mean & $\mathrm{N}$ & Standard deviation \\
\hline CRDB & 38.9250 & 10 & 19.33289 \\
NMB & 20.0870 & 10 & 18.59976 \\
NBC & 48.0130 & 10 & 18.23768 \\
Total & 35.6750 & 30 & 21.59874 \\
\hline
\end{tabular}

For the core deposits to total funding the mean calculated was much difference as it was 91.2 for NMB, 75.8 for NBC and 71.0 for CRDB. Standard deviation was not so much different. The test of one-way ANOVA at 0.05 significance level under this aspect indicated a significant difference between the commercial banks liquidity positions since the F statistic was 22.424 , while the F table was 5.14. With such results, the null hypothesis was rejected and the alternative hypothesis was accepted. Ho: There was no significant difference in liquidity positions among commercial banks in Tanzania.

For Gross loans to total deposit the mean was higher for NBC followed by CRDB and then NMB. There was significant difference in mean between the commercial banks, the standard deviation was not much difference as it ranges between 19.3 and 18.2. The test of one-way ANOVA at 0.05 significance level under this aspect indicated a significant difference between the commercial banks liquidity positions since the F statistic was 5.784, while the $\mathrm{F}$ table was 5.14. With such results, the null hypothesis was rejected and the alternative hypothesis was accepted.

\section{Conclusion}

This study intended to assess the liquidity position of the commercial banks industry with special reference of CRDB, NBC and NMB. The analysis was for ten years. Liquidity was evaluated in terms of core deposit to total funding, liquid asset to demand liabilities and gross loans to total deposit. Statistical analysis was done using one way Analysis of Variance (ANOVA) whereby the hypothesis was tested. Analysis indicated that the liquidity for the commercial banks is not uniform as they change over years. On other case, they show significant improvement while the other years are showing the decrease trend although not significant. Generally the performance of commercial banks was strong and this gives a reasonable assurance of the economic stability. 
The hypothesis tested was on the significant differences in liquidity positions for commercial banks. On this hypothesis it was revealed that there was no significant difference on the liquidity position.

\section{Acknowledgment}

The research is supported by the Ph. D. Programs Foundation of Ministry of Education of China (20090041110009), National Science Foundation of Ministry of China (71171032), and the central university special funds for basic research business expenses (DUT11RW202, DUT10ZD107)

\section{References}

Aikaeli. J. (2006). Efficiency of commercial bank in Tanzania. Retrieved from http://www.csae.ox.ac.uk/conferences/2008-EDiA/papers/387-Aikaeli.pdf

Aikaeli. J. (2006). Determinant of excess liquidity in commercial banks in Tanzania. Retrieved from http://papers.ssrn.com/sol3/papers.cfm?abstract_id=971750

ACCA Study Text. (2007). Managerial Finance. London: London BPP Publishing.

Adsera, X., \& Vinolas, P. (2003). A Financial and Economic Approach to Valuations. Financial Analyst Journal, 59, 80-89. http://dx.doi.org/10.2469/faj.v59.n2.2516

Baisi, D. (2005). Corporate Financial Management. Financial Times/Prentice Hall.

Barua, A. (2001). Liquidity Scenario in Commercial Banks of Bangladesh. Journal of business research, 3, 1-16.

Banking and financial institution Act (BFIA). (1991). United republic of Tanzania.

Bank of Tanzania. (2007). Risk based supervision framework.

Bank of Tanzania (BOT). (2011). United Republic of Tanzania.

Chijoriga, M. M. (1997). Application of credit scoring and financial distress prediction models to commercial banks' lending: the case of Tanzania. Vienna: Wirts Chaftsnnversitat Wien (WU).

George Foster. (1986). Financial Statement Analysis (2nd ed.). New York: Prentice Hill.

Bank for international settlement. (2009). International framework for liquidity risk measurement, standards and monitoring. Retrieved from http://www.bis.org/publ/bcbs188.pdf

Mathias, D., \& Nikolaou, K. (2009). Funding liquidity risk definition and measurement. European central bank. Retrieved from http://www.ecb.int/pub/pdf/scpwps/ecbwp1024.pdf

Nordic Investment Policy. (2009). Liquidity policy of commercial banks. Retrieved from http://www.nib.int/filebank/755-LiquidityPolicy.pdf

Shin. H., \& Adam T. (2007). Liquidity and leverage position of commercial banks. Retrieved from http://www.princeton.edu

Kothari, C. R. (1998). Research Methodology: Methods and Techniques (7th ed.). New Delhi, India.

Rychtarik, S. (2009). Liquidity scenario analysis in Luxembourg banking sector. BCDL working paper, Luxembourg: Banque central du Luxembourg.

Shapiro Allan C. (1991). Modern corporate finance. Maxwell Macmillan international edition.

Varnhorne, J. (2000). Financial management and policy (12th ed.). California, USA: Prentice Hall.

Timothy .V. (2010). The financial performance of commercial banks in Tanzania. Retrieved from http://ssrn.com/abstract=1858344

Vodova, P. (2011). Liquidity of Czech commercial banks and its determinant. International Journal Mathematical Models and Methods in Applied Science. 